\title{
PENGARUH CASH RATIO, TIME INTEREST EARNED DAN RETURN ON ASSET TERHADAP KEBIJAKAN DEVIDEN PADA PERUSAHAAN MANUFAKTUR YANG TERDAFTAR DI BURSA EFEK INDONESIA
}

\author{
Gema Ade Putra, Aminar Sutra Dewi \\ Sekolah Tinggi Ilmu Ekonomi KBP \\ gemmaadeputra@gmail.com
}

\begin{abstract}
The aims of this study is to analyze the influence of cash ratio and return on asset toward the dividen policy. This study is focused on manufacturing company listed on Indonesia Stock Exchange from 2011-2015. The method of data collection is purposive sampling. There are 35 datas in this observation during five years. This study used secondary data from Indonesia Stock Exchange (IDX) with panel regression as statistical tool. This study shows that cash ratio has positive significant effect to dividend policy, and ROA a negatif and don't significant effect to dividend policy.
\end{abstract}

Keywords : dividend policy, cash ratio, return on asset

\section{PENDAHULUAN}

Perusahaan baik secara keseluruhan, skala kecil, menengah maupun skala besar sesungguhnya memiliki tujuan primer yang sama yaitu untuk menghasilkan laba, meningkatkan kesejahteraan pemilik perusahaan, serta menyediakan produk spesifik untuk menjawab kebutuhan tertentu masyarakat salah satu tujuan utama perusahaan selain menghasilkan laba adalah meningkatkan kesejahteraan pemilik perusahan atau pemegang saham.

Keputusan membagikan dividen merupakan suatu masalah yang sering dihadapi perusahaan. Manajemen mengalami kesulitan untuk memutuskan apakan akan membagi dividen atau akan menahan laba untuk diinvestasikan kembali. Ini disebabkan keputusan dividen dapat mempengaruhi secara signifikan kebutuhan pembiayaan eksternal perusahaan. Dengan kata lain jika perusahaan membutuhkan pembiayaan, semakin besar dividen tunai yang dibayarkan maka semakin besar jumlah pembiayaan yang harus didapatkan dari eksternal melalui pinjaman atau penjualan saham. Jumlah dividen yang dibagikan tergantung kepada kebijakan dividen masing-masing perusahaan.

Menurut Subramanyam (2005:10) kebijakan dividen terkait dengan analisis penilaian perusahaan yang mengestimasikan nilai intrinsik perusahaan. Penilaian ini dipengaruhi oleh nilai pasar saham yang diperjual belikan, jumlah saham beredar, laba tahunan perusahaan, serta pembayaran dividen yang dilakukan oleh perusahaan.Ada berbagai teori mengenai kebijakan dividen ini, baik dari sudut pandang investor dan perusahaan. Dari penjelasan diatas dapat disimpulkan jika terjadi peningkatan cash ratio maka rasio dividen pun akan meningkat artinya jika perusahaan memiliki rasio kas yang besar maka perusahaan akan mampu menjamin 
hutangnya dengan kas yang ada, berarti kas yang masih tersedia dapat digunakan untuk membayar dividen pada pemegang saham akan tetapi dengan memperhatikan jumlah minimal kas yang harus tersedia di perusahaan pada akhir periode.

Menurut Kasmir (2007:115) rasio ini membandingkan laba bersih sesudah pajak dengan total aset sehingga penggunaan aset perusahaan dapat dilihat keefisienannya, semakin tinggi rasio ini maka semakin baik kinerja perusahaan. Semakin baik kinerja keuangan perusahaan, maka tujuan perusahaan untuk mensejahterakan pemegang sahamnya mudah untuk dicapai. Dari penjelasan di atas maka dapat disimpulkan jika nilai ROA mengalami peningkatan berarti semakin mampu perusahaan mengelola investasinya yang akan berdampak kepada peningkatan return.

Menurut Brigham (2001:65) faktor yang mempengaruhi kebijakan dividen adalah kendala atas pembagian dividen yang terdiri dari ketersediaan kas, perjanjian hutang, dan fluktuasi laba. Ketersediaan kas dapat diukur dengan cash ratio agar nantinya dapat melihat bagaimana kemampuan kas dalam menjamin hutang jangka pendek sehingga sisanya bisa digunakan untuk membayar dividen, perjanjian hutang yang diukur dengan time interest earned yang dapat melihat bagaimana tingkat keamanan risiko kredit perusahaan serta kesehatan perusahaan nantinya, apakah akan mengalami kesulitan keuangan atau tidak sehingga dividen dapat dibagikan dengan aman dan fluktuasi laba yang diukur dengan ROA berguna untuk melihat apakah perusahaan mampu menghasilkan laba melalui aset untuk nantinya dibagikan kepada pemegang saham.

Penelitian sebelumnya mendukung teori yang ada seperti penelitian yang dilakukan oleh Mahaputra (2014:70) bahwa ROA memiliki pengaruh signifikan terhadap DPR dan juga penelitian oleh Sandy (2013:75) yang juga menyatakan ROA secara parsial memiliki pengaruh signifikan terhadap dividen kas. Namun, penelitian Deitiana (2009:63) menyatakan bahwa ROA tidak berpengaruh terhadap DPR.

Berdasarkan masalah yang dipaparkan diatas serta hasil penelitian sebelumnya yang belum menunjukan hasil yang konsisten maka peneliti tertarik untuk melakukan penelitian yang berjudul "Pengaruh Cash ratio, dan Return On Asset terhadap Kebijakan Dividen Perusahaan Manufaktur yang Terdaftar di Bursa Efek Indonesia" berikut:

Adapun masalah yang dapat dirumuskan pada penelitian ini adalah sebagai

1. Bagaimana pengaruh cash ratio terhadap kebijakan dividen perusahaan manufaktur yang terdaftar di Bursa Efek Indonesia pada tahun 2011-2015?

2. Bagaimana pengaruh return on asset terhadap kebijakan dividen perusahaan manufaktur yang terdaftar di Bursa Efek Indonesia pada tahun 2011-2015?

\section{LANDASAN TEORI}

\section{Pengertian Kebijakan Deviden}

Kebijakan dividen menurut Rudianto (2009:308) adalah bagian dari laba yang diperoleh perusahaan dan diberikan oleh perusahaan kepada pemegang saham sebagai imbalan atas kesediaannya menanamkan hartanya di dalam 
perusahaan.Dividen merupakan kompensasi yang diterima oleh pemegang saham selain capital gain dan tidak semua laba dibagikan kepada pemegang saham karena sebagian digunakan untuk investasi dan pengembangan perusahaan. Menurut Hery (2011:114) "Perusahaan yang memiliki tingkat akumulasi laba bersih yang cukup baik dari satu periode ke periode lainnya biasanya memiliki potensi untuk membagikan sebagian dari laba bersih kepada pemegang saham dalam bentuk dividen“.

\section{Pengertian Cash Ratio}

Kas dan setara kas menurut Murhadi (2013:16) adalah posisi kas yang dimiliki perusahaan baik dalam bentuk uang tunai maupun uang yang berada dalam rekening untuk transaksi harian perusahaan dan perlu dihitung rasio kecukupannya. Rasio kecukupan arus kas merupakan ukuran kemampuan perusahaan untuk menghasilkan kas dari operasi yang cukup untuk menutupi pengeluaran modal, investasi, persediaan dan dividen tunai (Subramanyam, 2010:111).

Pengertian cash ratio menurut Hanafi (2007:206) adalah rasio yang digunakan untuk melengkapi rasio likuiditas lainnya dimana rasio ini menggunakan aliran kas dari operasi yang dilaporkan dalam laporan arus kas. Kelebihan kas yang diperoleh dari operasi setelah semua kebutuhan modal kerja dan pembayaran hutang lancar telah dipenuhi. Dalam cash ratio perusahaan tidak perlu menunggu untuk menjual atau menagih utang lancar lainnya karena hanya melihat kemampuan kas saja.

Rasio kas adalah alat yang digunakan untuk mengukur seberapa besar uang kas yang tersedia untuk membayar utang.Rasio ini menunjukan kemampuan sesungguhnya bagi perusahaan untuk membayar utang-utang jangka pendeknya (Kasmir, 2013:138-139).

\section{Pengertian Return On Asset}

Rasio profitabilitas bertujuan untuk melihat kemampuan perusahaan menghasilkan laba baik penjualan, aset maupun modal sendiri, salah satunya adalah return on asset (Najmudin,2011:86). Rasio ini berfungsi untuk melihat kemampuan aset yang diinvestasikan dalam menghasilkan laba.

ROA menunjukan hasil (return) atas jumlah aset yang digunakan dalam perusahaan. ROA juga merupakan ukuran tentang efektivitas manajemen dalam mengelola investasinya agar menghasilkan return yang optimal (Kasmir, 2013:202).Sejalan dengan pendapat diatas (Murhadi 2013:64) pun mengatakan return on asset mencerminkan seberapa besar return yang dihasilkan atas setiap aset yang ditanamkan di perusahaan.

Sementara menurut Harahap (2010:305) ROA merupakan rasio yang berfungsi untuk melihat berapa laba bersih yang diperoleh perusahaan bila diukur dari segi asetnya.Return on asset diartikan oleh Syamsuddin (2007:63) adalah pengukuran kemampuan perusahaan secara keseluruhan di dalam menghasilkan keuntungan dengan jumlah seluruh aset yang tersedia di dalam perusahaan.

ROA sering digunakan manajemen untuk mengukur kinerja keuangan perusahaan dan menilai kinerja operasional dalam memanfaatkan sumber daya perusahaan. Nilai ROA yang semakin mendekati 1 berarti lebih baik karena setiap aset mampu menghasilkan laba selama kegiatan operasional. Semakin tinggi nilai rasio ini maka semakin baik keadaan dan kinerja keuangan suatu perusahaan. 


\section{Pengaruh Cash Ratio terhadap Kebijakan Deviden}

Menurut Brigham (2001:89) salah satu faktor yang mempengaruhi keputusan dividen yakni kendala atas pembagian dividen dimana subbagiannya adalah ketersediaan kas.Kas merupakan aset lancar dan merupakan unsur penting dalam cash ratio $(C R)$ jika CR bernilai tinggi maka perusahaan dapat membagikan dividen kas nya. Jika kas tersedia maka dividen akan bisa dibagikan. Pembayaran dividen pun tertera dalam laporan arus kas perusahaan dikarenakan laporan arus kas terdiri dari aktivitas operasi, investasi, pendanaan dimana kegiatan pendanaan termasuk ke dalamnya yaitu pembayaran dividen kepada pemegang saham (Hanafi, 2007:59). Sehingga jumlah kas yang ada mempengaruhi dividen yang akan dibayarkan.

Pembayaran dividen adalah arus kas keluar, arus kas keluar yang tinggi akan memungkinkan perusahaan lebih berfokus pada pembayaran dividen atau menyelesaikan hutangnya untuk mengurangi biaya. Sehingga semakin kuat cash ratio maka akan semakin besar kemampuan perusahaan membayar dividen.

Hal ini juga didukung oleh penelitian yang dilakukan oleh Wicaksana (2012:61) yang menyatakan cash ratio memberikan pengaruh positif dan signifikan terhadap DPR. Berarti semakin meningkat nilai cash ratio maka akan menyebabkan terjadi peningkatan pula pada DPR.

Dari uraian diatas, dapat dikembangkan bahwa hipotesis yang pertama adalah Diduga Cash Ratio berpengaruh positif dan signifikan terhadap kebijakan deviden pada Perusahaan Manufaktur yang terdaftar di Bursa Efek Indonesia.

\section{Pengaruh Return On Asset terhadap Kebijakan Deviden}

Menurut Stice (2009:138) dividen adalah pembagian kepada pemegang saham dari suatu perusahaan secara proposional sesuai dengan jumlah saham yang dipegang masing-masing pemilik.ROA merupakan analisis untuk melihat perusahaan menghasilkan pengembalian melalui investasi aset yang ada.Sehingga semakin besar rasio ini maka makin terjaminlah kedudukan pemilik karena dividen yang diberikan pun bernilai baik.

Menurut Kasmir (2013:202) hasil pengembalian investasi menunjukan produktivitas dari seluruh dana perusahaan, baik modal pinjaman maupun modal sendiri. Semakin kecil nilai rasio ini semakin kurang baik perusahaan. Artinya rasio ini digunakan untuk mengukur efektifitas dari keseluruhan operasi perusahaan.

Semakin besar ROA maka semakin besar dividen yang dibagikan, dikarenakan perusahaan mampu menghasilkan laba yang besar dari asetnya sehingga laba yang dihasilkan tadi dapat dibagikan kepada pemegang saham tentunya dengan memperhatikan berbagai aspek lain diantaranya investasi baru yang akan dilakukan perusahaan atau membayar kewajibannya dulu. Dividen yang diambil dari keuntungan bersih akan mempengaruhi DPR, perusahaan yang semakin besar keuntunganya akan membayar porsi pendapatan yang semakin besar sebagai dividen. Hal ini juga sejalan dengan penelitian Mahaputra (2014:70) yang menyatakan bahwa ROA memiliki pengaruh positif terhadap DPR. Sehingga jika ROA mengalami peningkatan maka akan berdampak ke peningkatan dividen kas perusahaan. 
Dari uraian diatas, dapat dikembangkan bahwa hipotesis yang kedua adalah Diduga ROA berpengaruh negatif dan tidak signifikan terhadap Tingkat Kebijakan Deviden pada Perusahaan Manufaktur yang terdaftar di Bursa Efek Indonesia.

\section{METODE PENELITIAN}

Penelitian ini digolongkan pada jenis penelitian kuantitatif. Penelitian kuantitatif menurut Sugiyono (2006) merupakan penelitian empiris di mana data adalah dalam bentuk sesuatu yang dapat dihitung/ angka. Penelitian kuantitatif data yang berbentuk angka atau bilangan yang diambil dari laporan keuangan mengenai pengaruh cash ratio $(\mathrm{X} 1)$, return on asset $(\mathrm{X} 2)$ terhadap dividen payout ratio $(\mathrm{Y})$ perusahaan manufaktur yang terdaftar pada Bursa Efek Indonesia periode 2011-2015.

Populasi adalah seluruh kumpulan elemen yang menunjukan ciri-ciri tertentu yang dapat digunakan untuk membuat kesimpulan dan memiliki karakteristik khusus (Sanusi, 2011:87). Populasi dari penelitian ini adalah perusahaan manufaktur yang terdaftar di Bursa Efek Indonesia periode 2011-2015 yang berjumlah 150 perusahaan.

Menurut Sanusi (2011:87) sampel merupakan bagian elemen populasi yang terpilih dengan menggunakan teknik sampling.Teknik pengambilan sampel yang digunakan adalah metode purposive sampling (teknik bertujuan). Menurut Sanusi (2011:95) purposive sampling adalah cara pengambilan sampel yang didasarkan pada pertimbangan-pertimbangan tertentu, terutama pertimbangan yang diberikan oleh sekelompok pakar atau expert. Adapun kriteria pengambilan sampel dalam penelitian ini adalah sebagai berikut:

a. Perusahaan manufaktur yang terdaftar di BEI dan masih listing dari periode 2011-2015.

b. Perusahaan manufaktur yang menerbitkan laporan keuangan secara lengkap dan memuat seluruh data yang diperlukan dalam penelitian.

c. Perusahaan manufaktur yang memiliki laba positif selama periode 2011 - 2015 dan menggunakan mata uang Rupiah dalam pelaporan keuangannya.

d. Perusahaan manufaktur yang membagikan dividen kas secara berturut-turut selama periode 2011-2015.

Berdasarkan kriteria di atas sehingga terdapat 7 perusahaan yang menjadi sampel penelitian yang dapat dilihat pada tabel berikut :

1. PT. Arwana CitraMulia, Tbk

2. PT. Astra Internasional, Tbk

3. PT. Astra Otoparts, Tbk

4. PT. Sepatu Bata, Tbk

5. PT. Charoen Pokphand Indonesia, Tbk

6. PT. Ekadharma International, Tbk

7. PT. Gajah Tunggal, Tbk

Jenis dan sumber data pada penelitian ini adalah berupa data sekunder bersifat kuantitatif. Dalam penelitian ini, peneliti menggunakan data panel, yaitu merupakan kombinasi dari data time series dan cross-section. Data sekunder yang digunakan dalam penelitian ini adalah laporan keuangan yang berhubungan dengan 
variabel penelitian. Teknik pengumpulan data pada penelitian ini adalah dengan studi kepustakaan dan observasi secara langsung dengan melihat laporan keuangan perusahaan secara online.

\section{Defenisi Operasional Variabel}

\begin{tabular}{|c|c|c|c|}
\hline No & Variabel & Defenisi & Pengukuran \\
\hline 1 & $\begin{array}{l}\text { Kebijakan } \\
\text { Deviden }\end{array}$ & $\begin{array}{l}\text { Kebijakan dividen } \\
\text { terkait dengan } \\
\text { penentuan jumlah } \\
\text { dividen yang akan } \\
\text { dibagikan dan dihitung } \\
\text { dengan dividen payout } \\
\text { ratio yaitu rasio yang } \\
\text { berguna untuk melihat } \\
\text { bagaimana proporsi } \\
\text { laba perusahaan } \\
\text { manufaktur yang } \\
\text { terdaftar di BEI } \\
\text { periode 2011-2015 } \\
\text { yang dibagikan } \\
\text { berbentuk dividen. }\end{array}$ & $\begin{array}{l}\mathrm{DPR}=\frac{\text { Dividen } / \text { Share }}{\text { Earning } / \text { Share }}=\frac{\text { Dividen }}{\text { NetIncome }} \\
=\ldots \%\end{array}$ \\
\hline 2 & Cash Ratio & $\begin{array}{l}\text { Rasio kas } \\
\text { menunjukan porsi kas } \\
\text { yang dapat menjamin } \\
\text { hutang jangka pendek } \\
\text { perusahaan } \\
\text { manufaktur yang } \\
\text { terdaftar di BEI } \\
\text { periode 2011-2015. }\end{array}$ & Cash Ratio $=\frac{\text { Kas }}{\text { Utang Lancar }}=\ldots$. satuan \\
\hline 3 & ROA & $\begin{array}{l}\text { Return on asset } \\
\text { menggambarkan } \\
\text { kemampuan } \\
\text { perusahaan } \\
\text { manufaktur yang } \\
\text { terdaftar di BEI } \\
\text { periode 2011-2015 } \\
\text { dalam menghasilkan } \\
\text { laba. Menunjukan } \\
\text { kinerja perusahaan } \\
\text { dalam mendapatkan } \\
\text { laba bersih melalui } \\
\text { investasi aset yang } \\
\text { dilakukan }\end{array}$ & $\begin{array}{l}\text { Return On Asset }= \\
\frac{\text { NetProfitAfterTax }}{\text { Total Asset }}=\ldots \text {....satuan }\end{array}$ \\
\hline
\end{tabular}

Teknik analasis data pada penelitian ini adalah menggunakan uji teknik analisis deksriptif dimana melihat seberapa erat hubungan antara variable $\mathrm{x}$ dan $\mathrm{y}$. kemudian menggunakan uji asumsi klasik yang terdiri dari uji normalitas, uji 
heteroskedasititas, uji multikolonieritas, dan uji autokorelasi. Selanjutnya analisis regresi berganda, uji kelayakan model dengan menguji uji $\mathrm{F}$, uji t, dan uji $R^{2}$. Rumus persamaan uji regresi berganda adalah sebagai berikut:

$$
\mathrm{Y}=\beta o+\beta 1 \mathrm{X}_{1 \mathrm{it}}+\beta 2 \mathrm{X}_{2 \mathrm{it}}
$$

Dimana :

$$
\begin{array}{ll}
\mathrm{Y} & =\text { Kebijakan deviden } \\
\beta o & =\text { Konstanta } \\
\beta 1-\beta 2 & =\text { Koefisien regresi } \\
\mathrm{X}_{1 \mathrm{it}} \quad=\text { Cash Ratio } \\
\mathrm{X}_{2 \text { it }}=\text { Return On Asset } \\
\varepsilon=\text { error }
\end{array}
$$

\section{HASIL DAN PEMBAHASAN}

Variabel yang diukur dalam penelitian ini yaitu cash ratio, return on asset, dan kebijakan deviden. Berikut penjelasan kondisi variabel cash ratio, return on asset, dan kebijakan deviden pada perusahaan manufaktur yang terdaftar di Bursa Efek Indonesia tahun 2010-2015. Hasil pengujian statistik deskriptif pada penelitian ini disajikan pada tabel 1 berikut :

\section{Tabel 1}

Deskriptif Statistik

\begin{tabular}{|l|l|l|l|}
\hline & $\begin{array}{l}\text { Dividen Payout } \\
\text { Ratio }\end{array}$ & Cash Ratio & Return On Asset \\
\hline Mean & 33.90000 & 0.214286 & 12.79143 \\
\hline Maximum & 78.90000 & 0.900000 & 33.90000 \\
\hline Minimum & 3.100000 & 0.10000 & 0.800000 \\
\hline Std. Dev. & 19.21172 & 0.197414 & 6.653941 \\
\hline Observations & 35 & 35 & 35 \\
\hline
\end{tabular}

Sumber: Hasil Olahan Statistik

\section{Dividen Payout Ratio (DPR)}

Untuk deskripsi DPR nilai secara menyeluruh terlihat pada Tabel 1 bahwa nilai rata-rata DPR tahun 2011-2015 sebesar 33,9 \%. Artinya secara rata-rata industrinya, perusahaan manufaktur mampu membagikan deviden dengan besaran nilai tersebut selama periode 2011-2015.

Nilai maksimum untuk rasio dividen ini adalah sebesar 78,9\%. Nilai minimun sebesar 3,10\%, artinya perusahaan tersebut hanya 78,9\% saja dari laba persahamnya. Perusahaan memiliki standar deviasi DPR sebesar 19,21\% artinya menunjukkan simpangan data relatif kecil, karena nilai mean-nya relatif kecil yaitu $33,9 \%$.

\section{Cash Ratio}

Dari Tabel 1 dapat diketahui bahwa rata-rata nilai cash ratio tahun 2011-2015 pada perusahaan manufaktur sebesar 0.2142 artinya dari keseluruhan data cash ratio perusahaan yang ada, perusahaan manufaktur memiliki kas sebesar 0.2142 untuk menjamin hutang lancarnya. Nilai maksimun sebesar 0.9000 , artinya jumlah kas yang tersedia diperusahaan untuk membayar hutang lancar adalah 
sebanyak 90 kali kewajiban. Nilai minimum sebesar 0.10000 artinya kemampuan perusahaan untuk menjamin Rp 10 hutangnya hanya sebanyak 0.10000 kas saja. Standar deviasi perusahaan sebesar 0.1974 menunjukkan simpangan data yang relatif kecil, karena nilainya lebih kecil daripada mean-nya yaitu 0.2142.

\section{Return On Asset (ROA)}

Dari Tabel 1 dapat dilihat rata-rata nilai ROA tahun 2011-2015 sebesar 12,79\%. Artinya perusahaan manufaktur mampu menghasilkan laba sebesar $12,79 \%$ dari keseluruhan asetnya. Nilai maksimun sebesar 33,90\%, artinya kemampuan perusahaan memperoleh laba sebesar 33,90\% dari keseluruhan asetnya. Nilai minimum sebesar $8 \%$, artinya kemampuan perusahaan mengalami penurusan sebesar $8 \%$ dari keseluruhan asetnya. Standar deviasi perusahaan yaitu sebesar 6,65 \% artinya menunjukkan simpangan data yang relatif kecil, karena nilainya lebih kecil daripada mean-nya yaitu $12,79 \%$.

\section{Uji Asumsi Klasik}

\section{a. Uji Normalitas}

Tabel 2

Hasil Normalitas Data

\begin{tabular}{|l|l|l|l|}
\hline Mean & 2.394221 & 20.29120 & 33.90000 \\
\hline Median & 2.498257 & 19.82306 & 31.20000 \\
\hline Maximum & 5.443741 & 35.60804 & 78.90000 \\
\hline Minimum & 0.572967 & 5.131548 & 3.100000 \\
\hline Std. Dev. & 1.161920 & 5.879669 & 19.21172 \\
\hline Skewness & 0.522377 & 0.022233 & 0.394104 \\
\hline Kurtosis & 2.987762 & 4.151011 & 2.753312 \\
\hline & & & \\
\hline Jarque-Bera & 1.592004 & 1.934920 & 0.994768 \\
\hline Probability & 0.451129 & 0.380047 & 0.608120 \\
\hline & & & 1186.500 \\
\hline Sum & 83.79774 & 710.1921 & 12549.06 \\
\hline Sum Sq. Dev. & 45.90198 & 1175.397 & \\
\hline & & & 35 \\
\hline Observations & 35 & 35 & \\
\hline
\end{tabular}

Sumber : data diolah

Dilihat pada Tabel 2 di atas bahwa data variabel dalam penelitian ini normal, dimana nilai pada probability pada variabel X1 adalah sebesat 0.451129 , pada variabel X2 adalah sebesar 0.380047, dan pada variabel Y adalah sebesar 0.608120 dimana probability $>0.05$ sehingga data dapat dikatakan berdistribusi normal.

\section{b. Uji Heteroskedastisitas}

\section{Tabel 3}

Hasil Uji Heteroskedasitas

\begin{tabular}{|l|l|l|l|}
\hline F-statistic & 7.564295 & Prob. F(2,32) & 0.5120 \\
\hline Obs*R-squared & 11.23523 & Prob. Chi-Square(2) & 0.5036 \\
\hline
\end{tabular}

Sumber : Hasil olahan data Eviews

Dari Tabel 3 di atas dapat dilihat bahwa nilai Obs*R-Squared adalah sebesar 11.23523 dengan probability sebesar 0.5036 , dimana nilai probabilitas $>0.05$ sehingga didapatkan kesimpulan bahwa data tidak bersifat heteroskedasititas. 


\section{c. Uji Multikolonieritas}

Tabel 4

Hasil Uji Multikoloneritas

\begin{tabular}{|l|l|l|}
\hline & X1 & X2 \\
\hline X1 & 1 & -0.04924 \\
\hline X2 & -0.04924 & 1 \\
\hline
\end{tabular}

Sumber : Hasil olahan data Eviews

Berdasarkan pada tabel 4 hasil olahan data terlihat nilai korelasi antara sesama variabel independen dibawah 0,8 sehingga dapat dikatakan bahwa sesama variabel independen tidak memiliki hubungan multikoloneritas.

\section{d. Uji Autokorelasi}

\section{Tabel 5}

Hasil Uji Autokorelasi

\section{Model \\ Durbin-Watson}

$$
1 \quad 1.073629
$$

Sumber : Hasil Olahan data Eviews

Tabel 5 di atas menunjukan hasil dari uji Durbin Watson adalah senilai 1,073629 dan berada pada daerah yang tidak terkena autokolerasi, sehingga dapat disimpulkan bahwa dalam model penelitian ini tidak mengandung masalah autokolerasi.

\section{e. Uji Regresi Berganda}

Tabel 6

\section{Hasil Uji Regresi Linear Berganda}

Dependent Variable: Y

Method: Least Squares

Date: 08/27/17 Time: 16:15

Sample: 135

Included observations: 35

\begin{tabular}{|l|l|l|l|l|}
\hline Variable & Coefficient & Std. Error & t-Statistic & Prob. \\
\hline \hline C & & & & \\
\hline X1 & 43.66862 & 14.17460 & 3.080765 & 0.0042 \\
\hline X2 & 4.264881 & 2.889462 & 1.476012 & 0.0275 \\
\hline \hline R-squared & -0.512676 & 0.571006 & -0.897847 & 0.3760 \\
\hline Adjusted R-squared & 0.025122 & \multicolumn{2}{|l|}{ Mean dependent var } & 33.90000 \\
\hline S.E. of regression & 0.335807 & S.D. dependent var & 19.21172 \\
\hline Sum squared resid & 19.55265 & Akaike info criterion & 8.865915 \\
\hline Log likelihood & 12233.80 & Schwarz criterion & 8.999231 \\
\hline F-statistic & -152.1535 & Hannan-Quinn criter. & 8.911936 \\
\hline Prob(F-statistic) & 10.42318 & Durbin-Watson stat & 1.073629 \\
\hline \hline
\end{tabular}

Sumber : Data Eviews 
Pada tabel di atas, maka dapat dituliskan persamaan sebagai berikut :

DPR $(Y)=43.66862+4.264881$ X1 -0.512676 X2

\section{Pengujian Hipotesis}

\section{Uji Statistik $F$}

Dari tabel 6 dihasilkan nilai F-Statistic sebesar 10.42318 dengan nilai signifikan probability F-Statistic adalah 0.005581, tingkat probabilitasnya lebih kecil dari 0,05 atau $<0,05$. Hal tersebut mengidentifikasikan bahwa semua atau salah satu variabel yaitu cash ratio dan return on asset berpengaruh secara signifikan terhadap kebijakan deviden yang diukur dengan dividen payout ratio.

\section{Uji Statistik $t$}

Pada hipotesis pertama pada penelitian ini adalah diduga cash ratio berpengaruh positif dan signifikan terhadap dividen payout ratio. Dari hasil pengolahan data dihasilkan cash ratio menunjukkan $\mathrm{t}$ hitung 1.476012 dengan nilai yang signifikan 0.0275 kurang dari tingkat alpha 0.05 dan koefisien $\beta$ sebesar 4.264881 menunjukkan nilai positif. Artinya Ha diterima yaitu cash ratio berpengaruh positif dan signifikan terhadap DPR (dividen payout ratio).

Pada hipotesis kedua pada penelitian ini adalah diduga ROA (return on asset) berpengaruh negatif dan tidak signifikan terhadap DPR (dividen payout ratio). Dari hasil pengolahan data yang dihasilkan ROA (return on asset) menunjukkan $t_{\text {hitung }-0.897847}$ dengan nilai yang tidak signifikan 0.3760 lebih dari tingkat alpha 0.05 dan koefisien $\beta$ sebesar -0.512676 menunjukkan negatif. Artinya Ha diterima. Sehingga hipotesis yang diajukan diterima yaitu ROA (return on asset) berpengaruh negatif dan tidak signifikan terhadap DPR (dividen payout ratio).

\section{Uji Koefisien Determinasi $\left(R^{2}\right)$}

Hasil estimasi pada Tabel 6 diperoleh nilai $\mathrm{R}^{2}$ sebesar 0.025122 . Hal tersebut berarti hanya 0.025122 DPR (dividen payout ratio) perusahaan manufaktur yang terdaftar di BEI tahun 2011-2015 dapat dijelaskan oleh dua variabel independent-nya secara bersama-sama, yaitu cash ratio $\left(\mathrm{X}_{1}\right)$ dan return on asset $\left(\mathrm{X}_{2}\right)$. Sedangkan selebihnya lagi ditentukan oleh variabel diluar penelitian ini, misalnya penjualan dan utang usaha.

\section{Pengaruh Cash Ratio Terhadap Kebijakan Dividen Perusahaan Manufaktur Yang Terdaftar Di BEI Periode 2011-2015}

Berdasarkan hasil uji hipotesis yang dilakukan ternyata rasio kas atau cash ratio ternyata memiliki pengaruh positif dan signifikan terhadap kebijakan dividen perusahaan manufaktur yang terdaftar di BEI periode 2011-2015. Hal ini menunjukan meningkatnya cash ratio akan menyebabkan kenaikan yang signifikan pada rasio dividen.

Hipotesis ini dikembangkan berdasarkan teori Brigham yang menyatakan bahwa kebijakan dividen dipengaruhi oleh ketersediaan kas, jika peningkatan kas terjadi maka dengan beberapa perhitungan perusahaan akan meningkatkan pembayaran dividennya ini berbeda dengan hasil penelitian yang dilakukan. Penelitian ini menunjukan adanya hubungan positif dan signifikan antara cash ratio dengan DPR perusahaan manufaktur.

Nilai positif pada hasil pengujian menunjukan bahwa adanya peningkatan kas dan setara kas dalam perusahaan maka akan menyebabkan kenainakan pada 
DPR. Semakin likuid suatu perusahaan maka akan semakin besar kemungkinan pembayaran yang dilakukan oleh perusahaan tersebut. CS juga dapat meningkatkan harapan investor terhadap kemampuan perusahaan membagikan dividen. Pembayaran dividen yang merupakan arus kas keluar sehingga free cash flow perusahaan lebih berfokus pada pembiayaan dividen untuk mengurangi biaya keagenan.

Jika kas tersedia dengan baik untuk melunasi kewajiban, maka kelebihan kas tersebut dapat digunakan untuk membayarkan dividen pada pemegang saham. Perusahaan yang memiliki laba ditahan yang cukup, tetapi memutuskan untuk menginvestasikan dalam bentuk aset rill maka perusahaan tidak akan membayarkan dividen dalam bentuk kas, akan tetapi pada perusahaan manufaktur yang menjadi sampel penelitian ini, laba ditahan tidak selalu digunakan untuk membentuk investasi baru, akan tetapi digunakan juga untuk mensejahterakan pemegang saham.

Hasil penelitian ini mendukung teori Brigham yang menyatakan bahwa ketersediaan kas dapat mempengaruhi kebijakan dividen (2001:89) Selain itu, hasil penelitian ini juga mendukung penelitian yang dilakukan oleh Wicaksana (2012:61) mengenai pengaruh CS, DER, dan ROA terhadap kebijakan dividen perusahaan manufaktur di BEI dengan kesimpulan CS berpengaruh signifikan terhadap rasio dividen.

Dengan demikian, dapat disimpulkan pada perusahaan manufaktur periode 2011-2015 cash ratio memiliki pengaruh positif dan signifikan terhadap kebijakan dividen. Ketika cash ratio mengalami peningkatan maka akan berdampak kepada peningkatan rasio dividen pula dikarenakan cash ratio yang bernilai baik.

\section{Pengaruh ROA Terhadap Kebijakan Dividen Perusahaan Manufaktur Yang Terdaftar Di BEI Periode 2011-2015}

Berdasarkan hasil uji hipotesis ditemukan bahwa ROA memiliki hubungan negatif dengan kebijakan dividen yang diukur dengan DPR. Hal ini memperlihatkan bahwa setiap kenaikan return on asset akan menyebabkan penurunan rasio dividen perusahaan manufaktur.

Pengaruh negatif ini disebabkan karena pada periode penelitian, perusahaan manufaktur cenderung mengalami penurunan pada laba bersihnya namun jumlah aset yang digunakan lebih besar daripada tahun sebelumnya. Terbukti dengan nilai ROA yang kecil dan mengalami penurunan namun rasio dividen yang ada bernilai besar dan meningkat. Selain tujuan untuk menaikan harga saham di pasaran perusahaan juga menjadi prioritas utama bagi perusahaan manufaktur untuk menaikan nilai perusahaan di mata investor. Salah satu caranya adalah dengan membagikan dividen dalam jumlah besar. Saat laba mengalami penurunan, perusahaan menetapkan dividen yang akan dibagikan dalam jumlah besar guna menaikan kembali nilai perusahaan dan memberikan prediksi bahwa peningkatan laba akan terjadi di periode selanjutnya.

Hasil penelitian ini sesuai dengan teori dari Horne (2013:222) yang menyatakan bahwa rasio dividen dapat menurun saat dividen saham digunakan untuk mempertahankan kas dan daripada meningkatkan dividen tunai ketika laba naik, perusahaan berkeinginan menahan lebih banyak bagian labanya dan menyatakan dividen dalam jumlah yang sedang, maka ketika laba naik dan dividen 
hampir tetap sama maka rasio akan mengalami penurunan. Inilah yang terjadi pada perusahaan manufaktur selama periode 2011-2015.

Adanya teori residual dividen juga mendukung kenapa ROA perusahaan meningkat akan mengakibatkan penurunan rasio dividen. Dalam menentukan dividen ada beberapa perhitungan perusahaan diantaranya memanfaatkan laba ditahan untuk memenuhi kebutuhan akan modal sendiri semaksimal mungkin serta membayarkan dividen saat ada sisa laba. Jika perusahaan menghasilkan laba besar dan digunakan untuk mencari investasi baru, tanpa menerbitkan saham baru maka rasio dividen akan bernilai kecil.

Penelitian sebelumnya yang juga mendukung bahwa ROA memiliki hubungan yang negatif dengan dengan DPR adalah penelitian yang dilakukan oleh Ekasiwi serta Sunarto (2004) yang menyatakan bahwa ROA berpengaruh negatif dan tidak signifikan terhadap dividen payout ratio. Penelitian Akhadiyah (2015:63) juga mendukung hasil penelitian ini, penelitian menganalisis tentang pengaruh profitabilitas, leverage dann growth terhadap kebijakan dividen ditemukan hasil bahwa ROA (profitabilitas) dan DER (leverage) berpengaruh negatif dan tidak signifikan terhadap DPR sementara growth tidak berpengaruh.

Jadi dapat disimpulkan pada penelitian ini ROA berpengaruh negatif dan tidak signifikan terhadap kebijakan dividen. Jika terjadi peningkatan ROA maka akan terjadi penurunan rasio dividen dikarenakan perusahaan manufaktur lebih memilih menggunakan laba ditahan untuk pemenuhan modal dan invetasi baru daripada menggunakan hutang.

\section{SIMPULAN}

Berdasarkan hasil penelitian dan pembahasan yang telah disajikan pada bab-bab sebelumnya, maka dapat diambil kesimpulan sebagai berikut:

1. Cash ratio memiliki pengaruh positif dan signifikan terhadap kebijakan dividen (DPR) perusahaan manufaktur yang terdaftar di BEI periode 2011-2015 yang ditunjukkan dengan nilai profitabilitasnya lebih kecil dari 0,05 yaitu 0.005581 .

2. ROA memiliki pengaruh negatif dan tidak signifikan terhadap kebijakan dividen (DPR) pada perusahaan manufaktur yang terdaftar di BEI periode 2011-2015 yang ditunjukkan dengan nilai profitabilitasnya lebih besar dari 0,05 yaitu 0.3760 .

\section{DAFTAR PUSTAKA}

Afriani, Fillya dan Ervita Safitri. 2014. "Pengaruh Likuiditas, Leverage, Profitabilitas, Ukuran Perusahaan dan Growth terhadap Kebijakan Dividen". Jurnal STIE MDP.

Afriyeni, A., \& Marlius, D. (2019). Analisis Tingkat Pengembalian Dan Risiko Investasi (Studi Pada Industri Manufaktur Yang Terdaftar Di Bursa Efek Indonesia). https://doi.org/10.31219/osf.io/cfb92 
Afriyeni, A., \& Marlius, D. (2017). Analisis Pengaruh Harga Saham Perdana Terhadap Abnormal Return Yang Diterima Investor Studi Pada Bursa Efek Indonesia. https://doi.org/10.31219/osf.io/8z7hx

Afriyeni, A., \& Marlius, D. (2018). Analisis Pengaruh Informasi Prospektus Perusahaan Terhadap Initial Return Saham Pada Pasar Perdana Di Bursa Efek Indonesia. https://doi.org/10.31219/osf.io/kt6c4

Akhadiyah, Widya. 2015. "Pengaruh Profitabilitas, Leverage Dan Growth Terhadap Kebijakan Inisiasi Dividen”. Skripsi. Universitas Negeri Yogyakarta

Ariefianto, Moch Doddy. 2012. Ekonometrika Esensi dan Aplikasi dengan Menggunakan Eviews. Jakarta: Erlangga

Asri, Upik Yuli. 2009. Pengaruh Rasio Keuangan Dalam Memprediksi Laba Masa Datang Pada Perusahaan Manufaktur Yang Terdaftar Di Bursa Efek Indonesia Periode 2002-2007. Skripsi. Universitas Negeri 11 Maret.

Atmaja, Lukas Setia. 2003. Manajemen Keuangan. Yogyakarta : Andi

Bank Indonesia. 2015. Kajian Stabilitas Keuangan No.24 Maret 2015. Jakarta : Bank Indonesia

Brealey, Richard A. Stewart C.Myers \& Alan J. Marcus 2007. Dasar-Dasar Manajemen Keuangan Perusahaan Edisi Kelima Jilid Dua. Jakarta : Erlangga

Brigham, Eugene F. Joel F Houston. 2001. Manajemen Keuangan 1 dan 2 edisi 8 . Jakarta : Erlangga

Brigham, Houston F. 2006. Foundamentals of Financial Management Dasar-Dasar Manajemen Keuangan. Jakarta : Salemba Empat

Brigham, Houston F. 2011. Dasar-Dasar Manajemen Keuangan Essentials of Financial Management Edisi 11 Buku 2. Jakarta : Salemba Empat

Deitiana, Tita. 2009. "Faktor-Faktor Yang Mempengaruhi Kebijakan Pembayaran Dividen Kas". Jurnal Bisnis dan Akuntansi. STIE Trisakti. Vol 1 hal 57-64

Firnanti, Friska. 2011. "Faktor-Faktor Yang Mempengaruhi Struktur Modal Perusahaan Manufaktur Di Bursa Efek Indonesia”. Jurnal Bisnis dn Akuntansi. STIE Trisakti. Vol 13. No 2 hal 119-128.

Haming, Murdifin \& Salim Basalamah. 2010. Studi Kelayakan Investasi Proyek dan Bisnis. Jakarta: Bumi Aksara 
Hanafi, Mamduh M. 2007. Analisis Laporan Keuangan. Yogyakarta: Unit Percetakan dan Percetakan Sekolah Tinggi Ilmu Manajemen YKPN

Hanum, Atiqa. 2016. "Indeks BEI 14 Maret 2016:Saham di Sektor Aneka Penguatan IHSG. www.market.bisnis.com. diakses 20 Maret 2016

Harahap, Sofyan Syafri. 2010. Analisis Kritis Laporan Keuangan. Jakarta : Rajawali Pers

Harmono. 2009. Manajemen Keuangan berbasis Balance Scorecard, Pendekatan Teori, Kasus, dan Riset Bisnis. Jakarta : PT. Bumi Aksara

Hery \& Widyawati. 2011. “Akuntansi Keuangan Menengah 2". Jakarta : PT. Bumi Aksara

Horne, James C Van \& John M. Wachowicz,Jr. 2013. Prinsip-Prinsip Manajemen Keuangan edisi 13 Buku 2. Fundamentals of Financial Management $13^{\text {th }}$ ed. Jakarta : Salemba Empat

Irianto, Agus. 2004. Statistik. Konsep Dasar, Apikasi dan Pengembangannya. Jakarta: Kencana.

Kasmir. 2010. Pengantar Manajemen Keuangan. Jakarta : Kencana

Kasmir. 2013. Analisis Laporan Keuangan. Jakarta:PT. Grafindo Persada

Kementrian Koordinator Bidang Perekonomian RI. 2015. Deregulasi Paket Kebijakan Ekonomi Nasional. Banjarmasin.

Keown, Arthur J, dkk. 2008. Prinsip dan Penerapan Manajemen Keuangan. Jakarta : Indeks

Mahaputra, Gede Agus dan Ni Gusti Putu Wirawati. 2014. "Pengaruh Faktor Keuangan dan Ukuran Perusahaan pada Dividen Payout Ratio Perusahaan Perbankan” Jurnal Akuntansi Universitas Udayana Vol. 9.3 Hal 75

Margaretha, Farah. 2011. Manajemen Keuangan untuk Manajer Nonkeuangan. Jakarta :Erlangga

Murhadi, Werner R. 2013. Analisis Laporan Keuangan Proyeksi dan Valuasi Saham. Jakarta : Salemba Empat

Najmudin. 2011. Manajemen Keuangan dan Aktualisasi Syari'ah Modern. Yogyakarta: CV.Andi Offset 
Nurraiman, Rialdi. 2013. " The Influence Of Profitability, Liquidity And Leverage To Dividen Payout Ratio On The Listed Manufactured Companies In Indonesia Stock Exchange’’Jurnal Skripsi Universitas Widyatama.

Pramita, Fenny. 2013. "Pengaruh Cash Ratio, ROA dan Growth Of Company Terhadap Dividen Payout Ratio". Jurnal Ilmu dan Riset Manajemen. Vol.2 No 4. Hal 13

Putimasurai, Sheny Febrina dan Tri indra Wijaksana. 2014. "Pengaruh Return On Equity, Current Ratio, Debt To Total Asset dan Total Asset Turnover Terhadap Cash Dividen Perusahaan Manufaktur Sub Sektor Kosmetik dan Barang Kepeluan Rumah Tangga yang Terdaftar di Bursa Efek Indonesia Periode 2008-2012. Jurnal Administrasi Bisnis. Universitas Telkom. Hal 35.

Rudianto.2009.Pengantar Akuntansi. Jakarta: Erlangga

Sandy, Ahmad. 2013. "Pengaruh Profitabilitas dan Likuiditas Terhadap Kebijakan Dividen Kas Pada Perusahaan Otomotif'. Jurnal Ilmu dan Riset Akuntansi. STIESIA Surabaya. Vol 1 No 1

Sanusi, Anwar. 2011. Metodologi Penelitian Bisnis. Jakarta: Salemba Empat

Suad, Husnan. 1998. Manajemen Keuangan: Teori dan Penerapan Keputusan Jangka Pendek, Jilid 2. Yogyakarta: BPFE-Yogyakarta

Subramanyam, dkk. 2005. Financial Statement Analysis Analisis Laporan Keuangan Edisi 8 Buku 1. Jakarta : Salemba Empat.

Subramanyam \& Jhon J Wild. 2010. Analisis Laporan Keuangan Financial Statement Analysis Edisi 10 Buku 2. Jakarta : Salemba Empat.

Sunarto. 2004. "Pengaruh Rasio Profitabilitas dan Leverage terhadap Return Saham Perusahaan Manufaktur di BEJ”. Jurnal STIE Stikubank Semarang, Hal.63-81.

Stice, Earl K. James D. Stice \& K. Fred, Skousen. 2009. Akuntansi Keuangan Buku 2 Intermediate Accounting. Jakarta: Salemba Empat

Swastyastu, Made Wiradharma dan Gede Adi Yuniarta. 2014. "Analisis Faktor-Faktor yang Mempengaruhi Kebijakan Dividen Payout Ratio yang Terdaftar di Bursa Efek Indonesia (BEI). E-Journal S1 Ak Universitas Pendidikan Ganesha. Volume 2 No:1. Hal 10. 
Syamsuddin, Lukman. 2007. Manajemen Keuangan Perusahaan Konsep Aplikasi dalam :Perencanaan, Pengawasan, dan Pengambilan Keputusan. Jakarta : PT. Grafindo Persada

Tandelilin, Eduardus. 2010. Portofolio dan Investasi. Yogyakarta : Kanisius

Warren, Niswanger, dkk. 2000. Prinsip-Prinsip Akuntansi Edisi 19 Jilid 2. Jakarta : Erlangga

Wicaksana, I Gede Anandhita. 2012. "Pengaruh Cash Ratio, Debt to Equity Ratio dan Return On Asset Terhadap Kebijakan Dividen Pada Perusahaan Manufaktur di Bursa Efek Indonesia. Tesis yang diterbitkan. Universitas Udayana

Winarno, Wing Wahyu. 2009. Analisis Ekometrika dan Statistika dengan Eviews Edisi Kedua. Yogyakarta : UPP STIM YKPN.

Yakub, Suardi. dkk. 2014. "Pengaruh Profitabilitas Dan Investmen Opportunity Set Terhadap Dividen Tunai Perusahaan Go Public Sektor Perbankan Bursa Efek Indonesia" Jurnal Sains dan Komputer. STMIK Triguna Dharma.Vol 13 .No 1 ISSN 1978-6603.

$w w w . i d x . c o . i d$ 